УДК 344.65

DOI https:/ / doi.org/10.32837 / yuv.v0i2.1708

\author{
O. Торбас, \\ кандидат юридичних наук, \\ доцент кафедри кримінального процесу \\ Національного університету «Одеська юридична академія»
}

\title{
ЗАСТОСУВАННЯ РОЗСУДУ ПРОКУРОРОМ У ПРОЦЕСІ НАДАННЯ ДОРУЧЕНЬ ТА ВКАЗІВОК ЩОДО ПРОВЕДЕННЯ СЛІДЧИХ ДІЙ
}

Відповідно до ч. 2 ст. 36 КПК України прокурор під час досудового розслідування здійснює нагляд у формі процесуального керівництва за особами, які такий досудовий розсуд проводять. Водночас необхідно зауважити, що процесуальне керівництво прокурором здійснюється саме на стадії досудового розслідування, й саме в межах такого керівництва прокурору надані досить широкі можливості застосовувати розсуд у кримінальному провадженні. I з огляду на їх значимість пропонується дослідити особливості реалізації прокурорського розсуду під час здійснення слідчих (розшукових) та негласних слідчих (розшукових) дій.

Р.Н. Гасанов, вивчаючи участь прокурора під час проведення гласних і негласних слідчих (розшукових) дій, зазначив, що до відповідних повноважень прокурора належать такі:

1) мати повний доступ до матеріалів, документів та інших відомостей, які стосуються досудового розслідування;

2) доручати слідчому, органу досудового розслідування проведення в установлений прокурором строк слідчих (розшукових) дій, негласних слідчих (розшукових) дій, інших процесуальних дій або давати вказівки щодо їх проведення чи брати участь у них, а за необхідності - особисто проводити слідчі (розшукові) та процесуальні дії в порядку, визначеному КПК України;

3) доручати проведення слідчих (розшукових) дій та негласних слідчих (розшукових) дій відповідним оперативним підрозділам;

4) скасовувати незаконні та необгрунтовані постанови слідчих;

5) ініціювати перед керівником органу досудового розслідування питання про відсторонення слідчого від проведення досудового розслідування та призначення іншого слідчого за наявності підстав, передбачених КПК України, для його відводу, або в разі неефективного досудового розслідування;

6) погоджувати або відмовляти в погодженні клопотань слідчого до слідчого судді про проведення слідчих (розшукових) дій, негласних слідчих (розшукових) дій, інших процесуальних дій у випадках, передбачених КПК України, чи самостійно подавати слідчому судді такі клопотання;

7) приймати процесуальні рішення у випадках, передбачених КПК України $[1$, c. 65]. Із такою позицією можна погодитись, проте лише частково. Дійсно, кожне із цих повноважень певною мірою належить (або може належати) від повноважень щодо здійснення процесуального керівництва за проведенням слідчих (розшукових) та негласних слідчих (розшукових) дій, однак такий обсяг повноважень усе ж таки виглядає штучно розширеним, адже далеко не всі повноваження прямо стосуються повноважень у частині проведення слідчих та негласних слідчих (розшукових) дій, а тому штучне збільшення такого переліку повноважень лише ускладнить процес їх дослідження. 
Хоча під час аналізу відповідних положень КПК України можна помітити, що прокурор володіє досить суттєвими повноваженнями як у частині забезпечення проведення слідчих (розшукових) дій, так і в частині особистого їх проведення. Ці повноваження сконцентровані в п. 4 ч. 2 ст. 36 КПК України, відповідно до якого прокурор має право доручати слідчому, органу досудового розслідування проведення у встановлений прокурором строк слідчих (розшукових) дій, негласних слідчих (розшукових) дій, інших процесуальних дій або давати вказівки щодо ї проведення чи брати участь у них, а за необхідності - особисто проводити слідчі (розшукові) та процесуальні дії в порядку, визначеному КПК України. $\mathrm{У}$ цьому разі такі повноваження можна поділити на чотири групи:

1) прокурор може доручати проведення слідчих (розшукових) та негласних слідчих (розшукових) дій слідчому;

2) прокурор може санкціонувати проведення слідчих (розшукових) та негласних слідчих (розшукових) дій;

3) прокурор може брати участь у проведенні слідчих (розшукових) та негласних слідчих (розшукових) дій;

4) прокурор може самостійно проводити слідчі (розшукові) дій.

У поданій статті аналізу підлягає прокурорський розсуд у процесі надання доручень слідчому під час проведення відповідних процесуальних дій, адже кримінальне процесуальне законодавство не встановлює чітких правил винесення відповідних доручень. Варто зауважити, що прокурор надає слідчому не лише доручення, a i вказівки, які $€$ обов'язковими для виконання слідчим (ч. 4 ст. 40 КПК України). Водночас законодавець не уточнює, що саме розуміється під указівками та дорученням та як саме вони відрізняються між собою, адже використовуються ці обидва формулювання в межах п. 4 ч. 2 ст. 36 КПК Украіни. В.В. Луцик зазначає, що вказівки про проведення слідчих (розшукових) дій, негласних слідчих (розшукових) дій, інших процесуальних дій, на відміну від доручень, даються прокурором у такому разі, коли кримінальна справа знаходиться у провадженні слідчого [2, с. 233]. Із такою позицією погодитись складно, адже будь-яке провадження знаходиться у слідчого, адже лише слідчий уповноважений на проведення досудового розслідування.

О.Д. Гринів стверджує, що вказівка прокурора - це процесуальне рішення прокурора, яке виноситься у процесі здійснення процесуального керівництва досудовим розслідуванням кримінального провадження слідчому, керівнику органу досудового розслідування 3 метою досягнення всебічності, повноти та об’єктивності досудового розслідування, спрямоване на усунення прогалин та неповноти слідства, що наділена ознаками імперативності та є обов'язковою для виконання [3, с. 211]. Повністю 3 такою позицією погодитись не можна, адже вказівки не можуть бути віднесені до процесуальних рішень прокурора, які, відповідно до ч. 3 ст. 110 КПК України, виносяться у формі постанови (або у формі обвинувального акту, яким висувається обвинувачення). Водночас автором було зроблено досить слушний акцент на ситуаціях, у яких прокурор може виносити вказівки, й такий висновок узгоджується з положеннями нормативно-правових актів.

Так, у п. 4 ч. 2 ст. 36 КПК України зазначено, що прокурор може надавати як доручення, так і вказівки щодо проведення слідчих (розшукових) дій та негласних слідчих (розшукових) дій, що підкреслює той факт, що доручення та вказівки повинні відрізнятись одна від одної. Водночас у КПК України вказівки прокурора майже не згадуються (на відміну від доручень).

Також необхідно зауважити, що, відповідно до ч. 1 ст. 41 КПК України, оперативні підрозділи органів Національної поліції, органів безпеки, Національного антикорупційного бюро Україн, Державного бюро розслідувань, органів, котрі здійснюють контроль за 
дотриманням податкового й митного законодавства, органів Державної прикордонної служби України здійснюють слідчі (розшукові) дії та негласні слідчі (розшукові) дії у кримінальному провадженні за письмовим дорученням слідчого, прокурора, а підрозділ детективів, оперативно-технічний підрозділ та підрозділ внутрішнього контролю Національного антикорупційного бюро України - за письмовим дорученням детектива або прокурора Спеціалізованої антикорупційної прокуратури. Таким чином, прокурор має право надавати вказівки щодо проведення слідчих (розшукових) дій та негласних слідчих (розшукових) дій лише слідчому, а оперативним підрозділам надають виключно доручення щодо проведення відповідних процесуальних дій. Отже вказівка передбачає такий вид реагування, який притаманний лише слідчому, але не працівникам оперативних підрозділів.

О.Д. Гринів у своєму визначенні підкреслив, що вказівка прокурора спрямована саме на усунення недоліків слідства. Така позиція виглядає найбільш правильною та влучною. Доручення надається слідчому прокурором у тому разі, коли прокурор на власний розсуд уважає за потрібне отримати в конкретному кримінальному проваджені докази. Тобто прокурор перед тим, як надати доручення слідчому, повинен:

1) проаналізувати матеріали кримінального провадження та оцінити вже зібрані докази;

2) встановити, які докази мають бути отримані задля встановлення обставин кримінального провадження, що підлягають доказуванню;

3) встановити, які слідчі чи інші процесуальні дії можуть бути проведені для отримання таких доказів;

4) сформувати відповідне доручення та ознайомити з ним слідчого.

На кожному із цих етапів прокурор повинен прийняти рішення на власний розсуд, адже законодавець не встановив, у якому саме разі зібрана сукупність доказів буде достатньою для доведення події кримінального правопорушення чи винуватості особи. Очевидно, що саме задля цього законодавець наділив прокурора і слідчого правом застосовувати розсуд у процесі прийняття юридично значущих процесуальних рішень.

Указівки ж доцільно розглядати як реакцію прокурора на результати вже проведених процесуальних дій або на хід досудового розслідування загалом. Указівки надаються слідчому в тому разі, якщо, наприклад, були допущені помилки під час проведення однієї процесуальної дії та їі необхідно провести повторно. Крім того, своїми вказівками прокурор може впливати на хід досудового розслідування, якщо він не задоволений його результатами. Тому оперативними підрозділами можуть надаватись лише доручення, а не вказівки, адже оперативні підрозділи не відповідають за хід усього досудового розслідування, а лише залучаються для проведення окремих процесуальних дій.

Крім того, з огляду на формулювання, які використовуються у КПК України (п. 4 ч. 2 ст. 36 КПК Украіни - «<..> вказівки щодо їх проведення <..>»), та Інструкції про організацію проведення негласних слідчих (розшукових) дій, а також використання ї результатів у кримінальному провадженні [4] (п. 4.11 - «Прокурор або слідчий за його вказівкою досліджує отриману у процесі проведення негласних слідчих (розшукових) дій інформацію»), можна зробити висновок, що прокурор також може надавати вказівки в тому разі, коли необхідно додатково роз'яснити порядок проведення відповідної процесуальної діiі. Тобто вказівка може стосуватись не лише самої слідчої (розшукової) або негласної слідчої (розшукової) дії, а й конкретного способу та порядку їі проведення, які будуть вимагатись від слідчого.

Відповідно, задля вибору між дорученням та вказівкою прокурор переду- 
сім повинен оцінити стан досудового розслідування та якої форми впливу потребує таке провадження - встановлення процесуальних дій, які ще не були проведені та у процесі проведення яких можуть бути отримані докази, котрі мають значення для кримінального провадження, або усунення недоліків попередніх процесуальних дій та негайний вплив на хід досудового розслідування зі сторони процесуального керівника. Можна зробити висновок, що під час прийняття відповідних рішень прокурор передусім у своєму розсуді має опиратись на стан кожного конкретного кримінального провадження та завдання, котрі мають бути виконані на відповідному етапі досудового розслідування, адже кримінальне процесуальне законодавство не містить конкретних правил, за яких прокурор зобов'язаний надавати слідчому вказівки або доручення.

У статті аналізується розсуд прокурора у процесі надання доручень та вказівок шодо проведення слідчих (розшукових) та негласних cлібчих (розиукових) дій. Автор зазначає, що законодавець не уточнюе, що саме розуліється під указівками та дорученням та як саме вони відрізняються між собою, адже у КПК використовуються обидва иі формулювання. Автор досліджуе погляди різних науковиів із вказаного питання та доходить висновку, що доручення надається слідчому прокурором у тому разі, коли прокурор на власний розсуд уважае за потрібне отримати в конкретному кримінальному проваджені докази. тобто прокурор перед тим, як надати доручення слідчому, повинен: 1) проаналізувати матеріали кримінального провадження та оцінити вже зібрані докази; 2) встановити, які докази мають бути отримані задля встановлення обставин кримінального провадження, що підлягають доказуванню; 3) встановити, які слідчі чи інші процесуальні дї можуть бути проведені для отримання таких доказів; 4) сформувати відповідне доручення та ознайомити з ним слідчого. Указівки ж доиільно розглядати як реакиію прокурора на результати вже проведених проиесуальних дій або на хід досудового розслідування загалом. Указівки надаються слідчому в тому разі, якщо, наприклад, були допущені помилки під час проведення однієї процесуальної дї та ї необхідно провести повторно.

Таким чином, автор робить висновок, шо задля вибору між дорученням та вказівкою прокурор найперше повинен оцінити стан досудового розслідування та якої форми впливу потребує таке провадження - встановлення процесуальних дій, які ще не були проведені та у проиесі проведення яких можуть бути отримані докази, котрі мають значення для кримінального провадження, або усунення недоліків попередніх проиесуальних дій та негайний вплив на хід досудового розслідування зі сторони процесуального керівника. у статті узагальнюеться, що під час прийняття відповідних рішень прокурор найперше у своєму розсудi має опиратись на стан кожного конкретного кримінального провадження та завдання, котрі мають бути виконані на відповідному етапі досудового розслідування, адже кримінальне процесуальне законодавство не містить конкретних правил, за яких прокурор зобов'язаний надавати слідчому вказівки або доручення.

Ключові слова: розсуд прокурора, вказівки та доручення прокурора.

Torbas O. Application of discretion by prosecutor in the process of issuing orders and instructions on conducting investigative actions

Article analyses discretion of prosecutor in the process of issuing orders and instructions on the conduct of investigative (search) and covert investigative (search) actions. In the 
article author notes that legislator does not specify what exactly is meant by orders and instructions and how exactly they differ from each other, because CPC uses both of these formulations. Author examines the views of various scholars on this issue and concludes that prosecutor gives orders to investigator to conduct investigative (search) and covert investigative (search) actions when it is necessary to obtain evidence in a particular criminal case. That is, prosecutor, before giving an order to the investigator, must: 1) analyse materials of the criminal proceedings and evaluate evidence that have been already collected; 2) establish what evidence must be obtained in order to establish the circumstances of the criminal proceedings; 3) establish what investigative or other procedural actions may be carried out to obtain such evidence; 4) form an appropriate order and acquaint investigator with it. Instructions should be considered as a reaction of prosecutor to the results of the already conducted procedural actions or to the course of the pretrial investigation. Instructions are provided to the investigator if mistakes were made in carrying out procedural action and it must be repeated.

Thus, author concludes that in order to choose between an order and an instruction, prosecutor must first assess state of the pre-trial investigation and what form of influence such proceedings require - establishment of procedural actions that have not yet been conducted and during which evidence can be obtained that are important for criminal proceedings, or to eliminate the shortcomings of previous procedural actions and the immediate impact on the course of the pre-trial investigation by prosecutor. In article author states that in order to make relevant decisions prosecutor must use his discretion according to the state of each specific criminal proceedings and tasks to be performed at the appropriate stage of pre-trial investigation, because criminal procedural law does not contain specific rules under which the prosecutor is obliged to give orders or instructions to the investigator.

Key words: discretion of the procedutor, orders and instructions.

\section{Література}

1. Гасанов Р.Н. Здійснення повноважень прокурором в частині проведення слідчих (розшукових) дій : дис. ... канд. юри. наук : 12.00.09. Одеса, 2017. 251 c.

2. Луцик В.В. Правовий статус та повноваження прокурора за новим КПК України. Митна справа. 2013. № 1(85). 4. 2. Kн. 1. C. 231-238.

3. Гринів О.Д. Вказівка прокурора як форма процесуального керівництва досудовим розслідуванням. Університетські наукові записки. 2016. № 57. С. 205-212.

4. Інструкція про організацію проведення негласних слідчих (розщукових) дій та використання їх результатів у кримінальному провадженні, затверджена Наказом Генеральної прокуратури України, Міністерства внутрішніх справ України, Служби безпеки України, Адміністрациї Державної прикордонної служби України, Міністерства фінансів Украіни, Міністерства юстиції України віо 16.11.2012 № $114 / 1042 / 516 / 1199 / 936 /$ 1687/5. URL: https: / / zakon.rada.gov.ua/ laws/show/v0114900-12 (дата звернення 27.05.2020). 